\title{
Identification of the Secondary Metabolites and Characterization of Lagerstroemia Loudonii T. \& B.
}

\author{
Fahrauk Faramayuda ${ }^{1 *}$, Faizal Hermanto ${ }^{1}$, Ari Sri Windyaswari ${ }^{1}$, Soraya Riyanti ${ }^{1}$, and Viola Aditya Nurhayati ${ }^{1}$ \\ ${ }^{1}$ Faculty of Pharmacy, Universitas Jenderal Achmad Yani, Cimahi, Indonesia. \\ *Corresponding Author: ramayuda.f@gmail.com
}

\begin{abstract}
Bungur (Lagerstroemia loudonii T. \& B) is a type of plant widely grown in Indonesia and can be found in teak forests, mixed forests, and is found as ornamental plants or protective trees on the roadside. In the fruit section, Lagerstroemia loudonii is used as antituberculous and antimalarial. On the bark, the part is used as antidiarrheal. Based on some parts of the Lagerstroemia loudonii plants' activity data, this plant has the potential to be developed into traditional medicine. Standardized traditional medicine material is necessary to identify efficacious compounds and characterization in some parts of Lagerstroemia loudonii. The purpose of this research is to develop Lagerstroemia loudonii into traditional herbal medicine or standardized herbal medicine. Identification of efficacious compounds and characterization of crude leaf drugs, bark, stems, and fruit of Lagerstroemia loudonii. The phytochemical screening phase of the crude drugs of leaves, bark, stems, and fruit ofLagerstroemia loudonii against includes examining alkaloids, flavonoids, quinones, tannins, polyphenols, saponins, steroids and triterpenes, monoterpenoids and sesquiterpenoids. The determination of the characteristics of raw material carried out includes nonspecific parameters. Nonspecific parameters are the determination of total ash content, water-soluble ash content, acid insoluble ash content. each experiment was carried out three times and calculated the average yield and deviation. Identification results of the class of efficacious compounds in some parts of the Lagerstroemia loudonii plant are on the leaves and fruits containing alkaloids, flavonoids, saponins, quinones, tannins, polyphenols, monoterpenoids, and sesquiterpenoids as well as steroids and triterpenoids. At the bark and stem, the bark contains alkaloids, flavonoids, saponins, quinones, tannins, polyphenols, monoterpenoids, and sesquiterpenoids. Characterization results of Lagerstroemia loudonii leaf extract total ash content $4.45 \pm 0.30 \% \mathrm{w} / \mathrm{w}$, water-soluble ash content $4.08 \pm 0.27 \% \mathrm{w} / \mathrm{w}$, acid insoluble ash content 0.59 $\pm 0.06 \% \mathrm{w} / \mathrm{w}$, the extract specific gravity was $0.59 \pm 0.063$. Lagerstroemia loudonii stem bark extract, total ash content 1.94 $\pm 0.12 \% \mathrm{w} / \mathrm{w}$, water-soluble ash content $1.47 \pm 0.03 \% \mathrm{w} / \mathrm{w}$, acid insoluble ash content $0.24 \pm 0.02 \% \mathrm{w} / \mathrm{w}$, the extract specific gravity is $0.82 \pm 0.01$. Lagerstroemia loudonii stem extract, total ash content $3.18 \pm 0.16 \% \mathrm{w} / \mathrm{w}$, water-soluble ash content $2.36 \pm 0.38 \% \mathrm{w} / \mathrm{w}$, acid insoluble ash content $0.43 \pm 0.07 \% \mathrm{w} / \mathrm{w}$, extract specific grafity $0.81 \pm 0.01$. Lagerstroemia loudonii fruit extract, total ash content $11.45 \pm 1.16 \% \mathrm{w} / \mathrm{w}$, water-soluble ash content $10.1 \pm 1.49 \% \mathrm{w} / \mathrm{w}$, acid insoluble ash content $1.46 \pm 0.88 \% \mathrm{w} / \mathrm{w}$,extract specific grafity $0.81 \pm 0.01$. Based on phytochemical screening data and the characterization of bungur plants potential to be developed into raw materials for traditional medicine
\end{abstract}

Keywords: Lagerstroemia loudonii, secondary metabolite, raw material characterization

\section{Introduction}

Medicinal plants to overcome the disease have long been carried out, since many years ago. Medicinal plants are the basis for the development of modern medicine for human health. Drug development and research traditional (mainly herbal) in line with the national market's needs that began to give great attention to traditional medicine. Based on the (2013) Riskesdas data, $49 \%$ of the community. Indonesia uses traditional medicinal ingredients to maintain health and fitness. Indonesia has a tropical climate, a variety of plants, some plants that can be used as medicinal ingredients traditional [1][2]. Therapy with traditional ingredients has become part of the culture of people in various parts of the world. Almost every country has its own culture about the use of nature (plants) for treatment [3]. Based on WHO estimates, more than $80 \%$ of developing countries' population depends on traditional ingredients to overcome their health problems [4]. The importance of specific information about traditional medicines through systematic testing, research and development so that their utilization and efficacy can be accounted for scientifically. One of the plants 
that has the potential to be developed into traditional medicine is Lagerstroemia loudonii.

A plant contains compounds drug that is Lagerstroemia loudonii. This part of the plant is frequently used as medicine for seeds, leaves, and bark. Seeds can be used to treat high blood pressure and diabetes. The leaves are used to treat urination stones, diabetes, and high blood pressure, while the bark part is used to treat diarrhea, dysentery, and urinary blood [5][6]. This plant is a tree with a height of about $10 \mathrm{~m}$ to $20 \mathrm{~m}$. Lagerstroemia loudonii plants are very widely found on the islands of Sumatra and Java, Indonesia. Generally, there are teak forests whose soil conditions are arid, while infertile land, such as the mixed forest of the Lagerstroemia loudonii plants, is tall trunks [7]. Lagerstroemia loudonii leaf extract from several solvents is known to have hypoglycemic activity both in vivo and in vitro [8][9][10][11]. In the fruit section, Lagerstroemia loudonii is used as antituberculous and antimalarial [12]. On the bark, the part is used as antidiarrheal [13].

Research on the standardization of several Lagerstroemia loudonii parts has never been reported, so it is necessary to analyze and observe the specific and nonspecific parameters of crude drugs of Lagerstroemia loudonii The specific and non-specific parameters including drying shrinkage, total ash content, acid insoluble ash content, and water-soluble extract content, ethanol-soluble extract content, and secondary metabolite content. This quality requirement applies to the crude drugs used for medical treatment and maintenance [14]. Secondary metabolite compounds in plants are usually spread evenly throughout plant parts but at different levels [15][16].

\section{Materials and Methods}

\subsection{Plant materials, chemicals and isntrument}

Plant materials used in this study were leaves, bark, stems, and bulgur fruit (Lagerstroemia loudonii T. \& B.). The plant material was obtained from the experimental garden of the medicinal plant Manoko Lembang, West Bandung. The authenticity of the test sample was confirmed at School of Life Sciences and Technology ITB. The result of determination shows that the sample is Lagerstroemia loudonii $\mathrm{T}$ and $\mathrm{B}$ with letter number 3767/I1.CO2.2/PL/2017.

The chemicals used in this study were distilled water, 96\% ethanol (Merck®), toluene (Merck®), ammonia, chloroform (Merck®), Mayer reagent, Dragendorff reagent, gelatin solution, $\mathrm{FeCl}_{3}$ reagent, $\mathrm{HCl} 2 \mathrm{~N}$, magnesium powder (Merck®), amyl alcohol (Merck®), KOH (Merck®), ether (Merck®), Liebermann-Bourchard reagent, vanillin sulfate reagent.
The tools used in this study are analytic scales, dryer cabinets, evaporator (Heidolph), silicate crusts, ovens, electric (Heidolph), furnaces, desiccators, water baths, filter paper, ash-free filter paper, aluminium foil, plastic wrap, drop pipette, volume pipette, spatial and stirring rod.

\subsection{Procedure}

Phytochemical screening. The phytochemical screening phase of the crude drugs of Lagerstroemia loudonii T. \& B's leaves, bark, stems, and fruit against includes examining alkaloids, flavonoids, quinones, tannins, polyphenols, saponins, steroids and triterpenes, monoterpenoids and sesquiterpenoids.

Identification of alkaloids. A total of $1 \mathrm{~g}$ of the sample was based on $5 \mathrm{~mL}$ of diluted ammonia, then crushed in a mortar, then added $20 \mathrm{~mL}$ of chloroform while continuing to crush. Then filtered, the filtrate is put into a test tube, and then 5 $\mathrm{mL}$ of $2 \mathrm{~N}$ hydrochloric acid is added. The mixture is shaken vigorously until two layers are formed. The acid layer is separated, then divided into three parts. The first part is used as blank; the second part is dripped with 2 to 3 drops of Mayer reagent and observed whether there is a white precipitate. The third part is dripped with 2 to 3 drops of Dragendorff reagent, observed whether or not there is a brown-orange deposit.

Identification of flavonoids. As much as $1 \mathrm{~g}$ of the sample is heated with water over a water bath, then filtered. Put 5 $\mathrm{mL}$ filtrate into a test tube and magnesium powder and $1 \mathrm{~mL}$ $2 \mathrm{~N}$ hydrochloric acid. The mixture is steam over the heat of water, then filtered. The filtrate is put into a test tube, and 5 $\mathrm{mL}$ amyl alcohol is added. The mixture is then shaken vigorously and left to separate. The presence of flavonoids is indicated by the formation of yellow in the amyl alcohol layer.

Identification of polyphenols. As much as $1 \mathrm{~g}$ of the sample is heated with water over a water bath, then filtered. The filtrate is dripped with 2 to 3 drops of iron (III) chloride reagent solution. The formation of green-black colour indicates the presence of polyphenols.

Identification of tannins. A total of $1 \mathrm{~g}$ of the sample is dissolved with $15 \mathrm{~mL}$ of water, then transferred into a test tube and boiled for several minutes, then filtered. The filtrate is dripped with $1 \%$ gelatin solution. Observed the presence or absence of white precipitate.

Identification of saponins. Several samples are stored in a test tube and heated with water on a water bath, then filtered. After cold, the filtrate in the test tube is shaken vigorously for 30 seconds. The formation of solid foam for no less than 10 seconds as high as $1 \mathrm{~cm}$ to $10 \mathrm{~cm}$ indicates saponins' presence, and the addition of 1 drop of $2 \mathrm{~N}$ hydrochloric acid does not disappear.

Quinone identification. Much as $1 \mathrm{~g}$ of the sample is heated with water over a water bath, then filtered. The filtrate is 
added 2 to 3 drops of potassium hydroxide solution. The presence of quinones is indicated by the formation of a solid red colour.

Identification of monoterpenoid and sesquiterpenoid. As much as $1 \mathrm{~g}$ of the sample is crushed with $20 \mathrm{~mL}$ of ether, then filtered. The filtrate is evaporated on the evaporating dish to dry. In the residue, the vanillin reagent drops $10 \%$ as much as 2 to 3 drops. The formation of colours shows the presence of monoterpenoid and sesquiterpenoid compounds.

Identification of steroids and triterpenoids. As much as $1 \mathrm{~g}$ of the sample is crushed with $20 \mathrm{~mL}$ of ether, then filtered. The filtrate is evaporated on the evaporating dish to dry. In the residue, there were 2 to 3 drops of Liebermann-Burchard reagent. The formation of violet or blue-green colour indicates the presence of steroid and triterpenoid compounds.

\subsection{Characteristics of raw material}

The determination of the characteristics of raw material carried out includes nonspecific parameters. Nonspecific parameters are the determination of total ash content, watersoluble ash content, acid insoluble ash content.

Determination of content, total ash level. Weighed $2 \mathrm{~g}$ of test extract that has been crushed, inserted into the silica crucible that has been incandescent sprinkled in the furnace at a temperature of $500{ }^{\circ} \mathrm{C}$ to $600{ }^{\circ} \mathrm{C}$ until the charcoal runs out and weighed.

Soluble ash content. The ash obtained from the total ash content determination was boiled in $25 \mathrm{~mL}$ of water for 5 min. Filtered using ash-free filter paper, washed with hot water. The residue put on the stove for $15 \mathrm{~min}$, then respawned at a temperature of about $450{ }^{\circ} \mathrm{C}$ until a fixed weight is obtained.

Ash levels not soluble in acid. The ash obtained from the total ash content determination was boiled in $25 \mathrm{~mL}$ hydrochloric acid for $5 \mathrm{~min}$. Filtered using ash-free filter paper, washed with hot water.

Table 1. Result of crude drugs phytochemical screening

\begin{tabular}{|c|c|c|c|c|}
\hline Secondary Metabolites & Leaf & Stem bark & Stem & Fruit \\
\hline Alkaloid & + & + & + & + \\
\hline Flavonoid & + & + & + & + \\
\hline Saponin & + & + & + & + \\
\hline Quinone & + & + & + & + \\
\hline Tannins & + & + & + & + \\
\hline Polyphenol & + & + & + & + \\
\hline Monoterpenes and Sesquiterpenes & + & + & + & + \\
\hline Steroid and Triterpenoid & + & - & - & + \\
\hline
\end{tabular}

Determination of extract specific gravity. Pycnometer measuring $10 \mathrm{~mL}$ are dried and have been weighed. The pycnometer was then added with $1 \mathrm{~mL}$ extract with a concentration of $1 \%$ and weighed.

Statistic analysis. Each experiment was carried out three times and calculated the average yield and deviation standard.

\section{Result}

The morphological characteristic of the sample is the tree has a height of $\pm 20 \mathrm{~m}$. Stem erect, woody, round, sympodial branching, dirty white. Compound leaves, opposite cross, oval, blunt base, and tip, pinnate leaf bone, smooth hairy surface, $10-12 \mathrm{~cm}$ long, $5-7 \mathrm{~cm}$ wide, cylindrical stalk shape (Figure 1).

Phytochemical screening of crude leaf drugs, stem bark, and Lagerstroemia loudonii was carried out to determine the content of secondary metabolites such as alkaloids, flavonoids, saponins, quinones, tannins, polyphenols, monoterpenoids and sesquiterpenoids and steroids, and phytochemical screening results on crude drugs in Table I. The specific test was also carried out on extracts, such as determining total ash content, water-soluble ash content and acid insoluble ash content, and determining extract specific gravity. The results of the examination of the characteristics of each ethanol extract are shown in Table 2.

Determination of total ash content aims to determine the total amount of substances remaining in the spawning, including physiological ash content derived from the plant itself and non-physiological ash derived from external contamination, such as air, soil, and water pollution. Determination of water-soluble ash levels indicates the presence of ash from water-soluble salts contained in the crude drugs. The determination of acid-insoluble ash content indicates the presence of silica in crude drugs. 

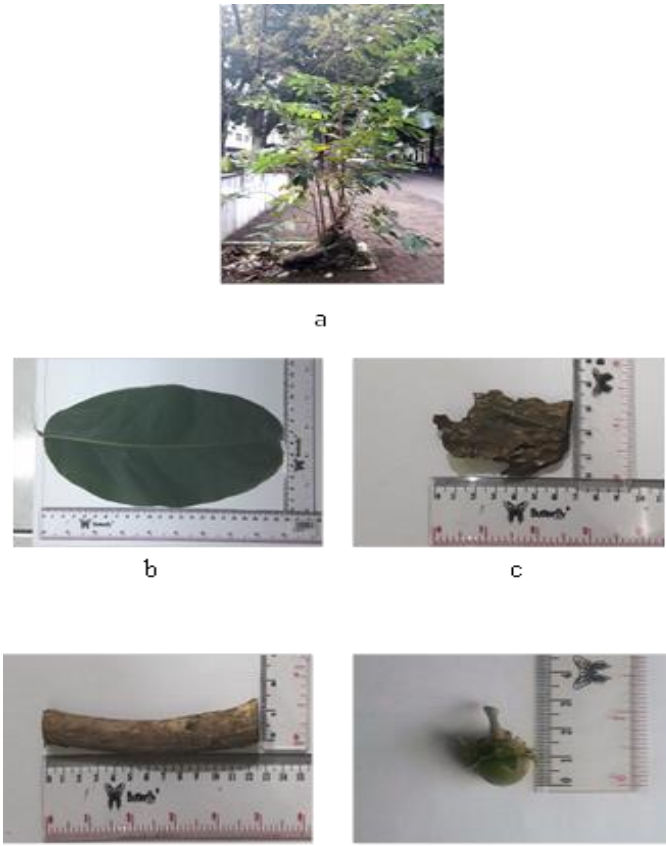

d

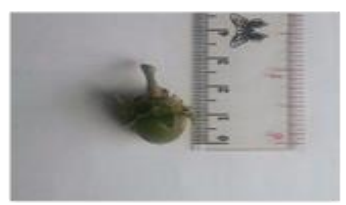

e

Figure 1. Parts of Lagerstroemia loudonii (a). Leaf (b), bark (c), stem (d), fruit (e)

\section{Discussion}

Leaves, bark, stem, and collected fruits are cleaned using running water and dried to avoid damage to the test material that can cause damage substances in crude drugs and increase the crude drug resistance to be stored for a long time. Dry crude drugs are then mashed to powder to facilitate the extraction process.

The formation of foam indicates saponin compounds after shaking, and the foam is not lost after adding a hydrochloric acid solution. Foam formed due to a combination of its constituent compounds, namely non-polar sapogenin chains and water-soluble polar side chains. Quinone compounds are shown by their ability to form yellow to red salts formed from the reaction of hydroquinone with a strong base $(\mathrm{KOH})$. The formation of blackish-blue shows polyphenol compounds due to the reaction between a phenyl group and a solution of iron (III) chloride. Tannin compounds are compounds belonging to the polyphenol group. Tannin is indicated by the formation of white deposits after added with gelatin. Tannin compounds have unique properties that can precipitate proteins.

The formation of colours indicates the presence of monoterpenoid and sesquiterpenoid compounds after adding $10 \%$ vanillin reagent. Monoterpenoids and sesquiterpenoids are compounds that make up essential oils. Steroid and triterpenoid compounds are shown by their ability to form green after the Liebermann-Burchard reagent addition. The colour formed is caused by an oxidation reaction through the formation of a conjugated double bond.
Table 2. Result of characteristic extract

\begin{tabular}{|c|c|c|c|c|c|}
\hline \multirow[b]{2}{*}{ No } & \multirow[b]{2}{*}{ Test } & \multicolumn{4}{|c|}{ Result } \\
\hline & & Leaf & $\begin{array}{l}\text { Stem } \\
\text { Bark }\end{array}$ & Stem & Fruit \\
\hline 1 & $\begin{array}{l}\text { total ash content } \\
\qquad(\% \mathrm{w} / \mathrm{w})\end{array}$ & $4.45 \pm 0.3$ & $1.42 \pm 0.12$ & $\begin{array}{c}3.185 \pm \\
0.166\end{array}$ & $\begin{array}{c}11.455 \pm \\
1.165\end{array}$ \\
\hline 2 & $\begin{array}{c}\text { water soluble } \\
\text { ash content (\% } \\
\text { w/w) }\end{array}$ & $\begin{array}{l}4.08 \pm \\
0.275\end{array}$ & $\begin{array}{c}1.472 \pm \\
0.032\end{array}$ & $\begin{array}{c}2.362 \pm \\
0.385\end{array}$ & $\begin{array}{l}10.1 \pm \\
1.492\end{array}$ \\
\hline 3 & $\begin{array}{l}\text { acid insoluble } \\
\text { ash content (\% } \\
\text { w/w) }\end{array}$ & $\begin{array}{c}0.595 \pm \\
0.063\end{array}$ & $\begin{array}{c}0.247 \pm \\
0.016\end{array}$ & $\begin{array}{c}0.43 \pm \\
0.077\end{array}$ & $\begin{array}{c}1.467 \pm \\
0.883\end{array}$ \\
\hline 4 & $\begin{array}{c}\text { extract specific } \\
\text { gravity }\end{array}$ & $\begin{array}{l}0.816 \pm \\
0.0047\end{array}$ & $\begin{array}{c}0.816 \pm \\
0.0033\end{array}$ & $\begin{array}{c}0.815 \pm \\
0.004\end{array}$ & $\begin{array}{l}0.814 \pm \\
0.0042\end{array}$ \\
\hline
\end{tabular}

Alkaloids are compounds derived from living things, mostly plants, generally synthesized, contain bound nitrogen in heterocyclic rings, and are alkaline and generally have activities biology at low doses. Alkaloids' physical properties are mostly crystalline or amorphous, generally colourless except berberine and betaine, alkaloid solubility free, or the salt is essential in isolation. Generally, the base will dissolve in organic solvents, pseudoalkaloid, and protoalkaloid will dissolve in water, and those containing quaternary ammonium are also water-soluble. The introduction of alkaloids is based on their ability to form compounds insoluble complex with metal-containing reagents such as Mayer reagent and Dragendorff reagent.

Flavonoids are one of the largest natural phenol groups. According to an estimate, approximately $2 \%$ of all carbon photosynthesis by plants is converted into flavonoids or closely related compounds. In-plant aglycone flavonoids (sugarless flavonoids bound) is in the form of a structure. Flavonoids are polyphenols and have the chemical properties of phenol compounds, which are slightly acidic to dissolve in base. The introduction of flavonoids is based on the carbonyl group's reduction reaction on the circumference of $\delta$-lakton becomes an alcohol group to form a hydroxy compound colour depends on the functional group bound to circumference A or B. The colour that occurs can be drawn by amyl alcohol.

Phenol compounds have to do with lignin bound as an ester or present in the leaves in an insoluble fraction in ethanol, or maybe contained in the fraction dissolved in 
ethanol, namely as a glycoside simple. Natural polyphenol compounds are easily recognized through the introduction phenol group, giving a blue-black colour with reagents iron (III) chloride.

Tannin is widespread in vascular plants, in angiosperms specifically for wood tissue. Tanin is easily recognized through cluster recognition phenol, giving blue-black colour with iron (III) chloride. To distinguish tannins from natural polyphenols used properties tannins, which can precipitate a $1 \%$ gelatin solution. Saponins are surface-active compounds and are like soap, and can be detected based on their ability to form foam of blood cells. Search for saponins in plants has stimulated by the need for sapogenin sources that can be obtained and quickly converted into animal sterols, which have important.

Triterpenoids and steroids Triterpenoids are compounds with a carbon frame from six isoprene units, and biosynthesis is derived from C30 hydrocarbons acyclic, which is squalene. The Triterpenoid can be chosen as a minimum of four classes of compounds: actual triterpene, steroids, saponins, and cardiac glycosides. This compound has a cyclic structure of compound groups. Triterpenoids are compounds of secondary metabolite groups that have a similar basic structure. Steroids are compounds that contain the cyclopentane perhydrophenanthren core. Steroids are a component that is found in natural materials that are very widely distributed.

Diversity of biological activities from steroids, including controls in the reproductive tract in humans, is included in hormone group reproduction. The introduction of triterpenoid and steroid compounds is based on their ability to form colours with Liebermann Burchard reagents (acetic anhydride concentrated $\mathrm{H}_{2} \mathrm{SO}_{4}$ ) with most triterpene and sterols giving a green colour blue.

Previous studies reported the inhibitory activity of the glucosidase enzyme extract and fractions (water, ethyl acetate, and n-hexane) of Lagerstroemia loudonii stem bark containing alkaloids, flavonoids, polyphenols, tannins, quinones, saponins, and monoterpenoids as well as sesquiterpenoids compounds. in vitro showed the results were able to inhibit the activity of the $\alpha$-glucosidase enzyme with IC50 values of $240.53 \mathrm{~g} / \mathrm{mL}, 186.111 \mathrm{~g} / \mathrm{mL}, 79.479$ $\mathrm{g} / \mathrm{ml}$, and $113.101 \mathrm{~g} / \mathrm{mL}$, respectively [17][18].

From the results of the examination of specific and nonspecific parameters of the Lagerstroemia loudonii plant, it has the potential to be developed into a standardized traditional medicine. In previous studies, it was reported that ursolic acid is one of the compounds found in Lagerstroemia loudonii and is a triterpenoid group and has pharmacological activity as antidiabetic [19]. This study reported the presence of triterpenoid compounds in the leaves and fruit of Lagerstroemia loudonii. Based on the potential of Lagerstroemia loudonii as an antidiabetic agent, this research can be used as the basis for further research that leads to in vivo antidiabetic activity testing, especially the selection of plant parts used.

\section{Conclusion}

Lagerstroemia loudonii has the potential to be developed as raw material for traditional herbal medicines and standardized herbal medicines.

\section{Acknowledgement}

Research institute and community service Universitas Jenderal Achmad Yani and Kementerian Riset, Teknologi, dan Pendidikan Tinggi Republik Indonesia (Kemenristekdikti RI) for their support in this study.

\section{Reference}

[1] Hariana, H. A., 2004, Medicinal Plants and Their Benefits, 1st Mold, Penebar Swadaya, Jakarta.

[2] Muhlisah, F. 2006, Family Medicine Park, 13th Printing, Self-Help Spreader. Jakarta

[3] Lee, K.H., H.K. Wang, H. Itokawa, and S.L. MorrisNitschke. 2000. Current perspectives on Chinese medicines and dietary supplements in China, Japan, and the United States. Journal of Food and Drug Analysis 8 (4): 219-228.

[4] Khan, M.T.H., L. Lampronti, D. Martello, N. Bianchi, S. Jabbar, M.S.K. Choudhuri, B.K. Datta, and R. Gambari. 2002. Identification of pyrogallol as an antiproliferative compound present in extracts from the Emblica medicinal plant: effect on in vitro cell growth of human tumor cell lines. International Journal of Oncology 20: 187-192.

[5] Heyne, K., 1987, Indonesian Useful Plants, Volume III, a.b. Jakarta Forestry Research and Development Agency, Publisher of the Sarana Wana Jaya Foundation, Jakarta.

[6] Dalimartha, S., 2003, Atlas of Indonesian Medicinal Plants, Volume II, Trubus Agriwidya, Jakarta.

[7] Setiawan, D. 2000. Atlas of Indonesian Medicinal Plants. Volume 2. Trubus Agriwidya, Jakarta.Mishra, Y., M.S.Y. Khan, R. Zafar, and S.S. Agarwal. 1990. Hypoglycaemic activity of leaves of Lagerstroemia speciosa L. Press. Indian Journal of Pharmacology 22: 174-176.

[8] Kakuda, T., I. Sakane, T. Takihara, Y. Ozaki, H. Takeuchi, and M. Kuroyanagi. 1996. Hypoglycemic effect of extracts from Lagerstroemia speciosa L. leaves in genetically diabetic KKAy mice. Bioscience, Biotechnology, and Biochemistry 60 (2): 204-208.

[9] Liu, F., J. Kim, Y. Li, X. Liu, J. Li, and X. Chen. 2001. An extract of Lagerstroemia speciosa L. has insulin-like glucose uptake-stimulatory and adipocyte 
differentiation inhibitory activities in 3T3-L1 cells. Journal of Nutrition 131: 2242-2247.

[10] Hayashi, T., H. Maruyama, R. Kasai. K. Hattori, S. Takasuga, O. Hazuki, K. Yamasaki, and T. Tanaka. 2002. Ellagitannins from Lagerstroemia speci as activators of glucose transport in fat cells. Planta Medica 68: 173-175.

[11] Boonphong, S., Mopoung, S., Maneerungroj, C., Yannalarp, P., \& Udeye, V. 2003. Bioactivity Screening of Lagerstroemia. Naresuan University Research Report. Budhi, M., 1994. The stages of developing traditional medicine. Udayana Medical Magazine 5: 107-113.

[12] Suzuki, Y., Unno, T., Ushitani, M., Hayashi, K., \& Kakuda, T. (1999). Antiobesity Activity of Extracts from Lagerstroemia speciosa L. leaves on female KKAy Mice, (November), 791-795.

[13] Anonim., 2008, Indonesian Herbal Pharmacopoeia, Ministry of Health of the Republic of Indonesia, Jakarta
[14] Robinson, T., 1991, High Plant Organic Content, 6th Edition, a.b. Kosasih Padmawinata, ITB, Bandung.

[15] Markham, K. R., 1988, How to Identify Flavonoids, a.b. Kosasih Padmawinata, ITB, Bandung.

[16] Saleh, M, I., 2016. Inhibitor Activity of -Glucosidase Enzyme Extract and Bark Fraction of Batang Bungur (Lagerstroemia loudonii T. \& B.) In Vitro. Thesis. Universitas Jenderal Achmad Yani.

[17] Pratiwi. S. 2016. Phytochemical Study of Bungur Stem Bark (Lagerstroemia loudonii T. \& B.). Thesis. Universitas Jenderal Achmad Yani.

[18] Sirimethawong, K., Sriwattanawarunyoo, C., \& Udeye, V.2013. Waxes and Triterpene acids from Lagerstroemia loudonii fruit. International Journal of Science. 10(2), 33-43.

[19] Sirimethawong, K., Sriwattanawarunyoo, C., \& Udeye, V.2013. Waxes and Triterpene acids from Lagerstroemia loudonii fruit. International Journal of Science. $10(2)$, 33-43. 